University of Rhode Island

DigitalCommons@URI

The Rhode Island Current Conditions Index

Economics

$2-2008$

\title{
Rhode Island Current Conditions Index - February 2008
}

Leonard Lardaro

University of Rhode Island, lardaro@uri.edu

Follow this and additional works at: https://digitalcommons.uri.edu/ricci

Part of the Econometrics Commons

Terms of Use

All rights reserved under copyright.

\section{Recommended Citation}

Lardaro, Leonard, "Rhode Island Current Conditions Index - February 2008" (2008). The Rhode Island Current Conditions Index. Paper 59.

https://digitalcommons.uri.edu/ricci/59

This Article is brought to you for free and open access by the Economics at DigitalCommons@URI. It has been accepted for inclusion in The Rhode Island Current Conditions Index by an authorized administrator of DigitalCommons@URI.For more information, please contact digitalcommons-group@uri.edu. 


\section{GURRENT}
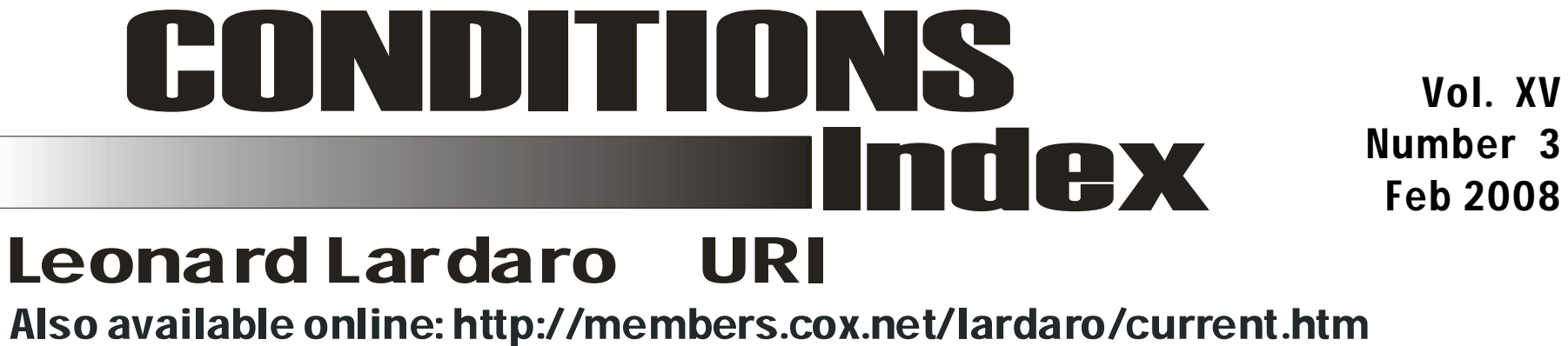

In terms of economic performance, 2008 has been a historic year for Rhode Island. It started the year with its economy far worse than flat - a substantially worsening economic picture. For January, the Current Conditions Index was 8, tied for its lowest value ever. Only one indicator improved, the Manufacturing Wage, which ironically reflected skil shortages in the midst of all the economic weakness. In February, Rhode Island set a new record: for the first time in its history (values have been calculated all the way back to 1980), the Current Conditions Index registered values of 8 for two consecutive months. Once again for February, the only improving indicator was the Manufacturing Wage.

Whenever monthly economic results appear to be dismal, and we are moving into unchartered territory here, I always look at the "comp" period performance for each indicator. Was last February's value atypical? If so, there is an excuse for an indicator failing to improve this February. Guess what? No such luck this February! Actually, the $\mathrm{CCl}$ values for last year were almost all adjusted lower based on revised labor market data. What the $\mathrm{CCl}$ indicators show all too vividly is a labor

CCI Indicators - \% Change

Government Employment $\quad-0.3$

\begin{tabular}{l|l} 
US Consumer Sentiment & -22.4
\end{tabular}

\begin{tabular}{l|l} 
Single-Unit Permits & -10.7
\end{tabular}

Retail Sales $\quad-1.3$

\begin{tabular}{ll|} 
Employment Services Jobs $\quad-11.7$ \\
\hline
\end{tabular}

Priv. Serv-Prod Employment $\quad-0.5$

\begin{tabular}{ll} 
Total Manufacturing Hours $\quad-6.9$ \\
\hline
\end{tabular}

\begin{tabular}{l|l} 
Manufacturing Wage & $2.8^{\prime} \mathbf{Y}$
\end{tabular}

\begin{tabular}{l|l}
\hline Labor Force & -1.2 \\
\hline
\end{tabular}

\begin{tabular}{l|l} 
Benefit Exhaustions & 24.0
\end{tabular}

\begin{tabular}{l|l}
\hline New Claims & 11.7 \\
\hline
\end{tabular}

\begin{tabular}{l|l} 
Unemployment Rate & 18.4
\end{tabular}

$\mathbf{Y}=$ Improved Value

market that is becoming unhinged and weakness spread throughout Rhode Island's entire economy. I hate to be that negative, but that is the accurate assessment at present.

Rhode Island's economic implosion thus continued unabated in February. Anyone who denies that Rhode Island is in a recession is clearly delusional. We are, as I noted last month, in a second recession phase, where prior economic activity levels become ever-more unattainable. What is the only thing that could possibly be worse? Having to eliminate a large budget deficit amid all this weakness. Welcome to Rhode Island's world!
All is not lost, however. Keep in mind that the $\mathrm{CCl}$ reflects the underlying momentum of our state's economy, not its overall level of activity. So, while the levels of almost all indicators are falling, many remain at "reasonable" levels based on history. Those levels will continue to become increasingly unsustainable, however.

Overall, there was no shortage of disappointing performances in February. The list of indicators failing to improve at doubledigit rates rose sharply to half of all indicators in February. Among these, US Consumer Sentiment fell by 22.4 percent, Employment Service J obs, a leading labor market indicator, dropped by 11.7 percent, New Claims, which reflects layoffs, rose by 11.7 percent, and Benefit Exhaustions, a measure of long-term unemployment, jumped 24 percent. While our Unemployment Rate rose all the way to 5.8 percent, it would have easily exceeded 6 percent had some unemployed not dropped out of the Labor Force (it fell by 1.2 percent).

Let me end again on a positive note. For February, SingleUnit Permits fell by 10.7 percent to below 1,000 units annually. While this might sound disastrous, this little new construction helps us reduce our inventory of unsold homes.

I encourage everyone to look carefully at these numbers. As difficult as it is for a writer like me to admit, at present, the numbers speak far louder than words!

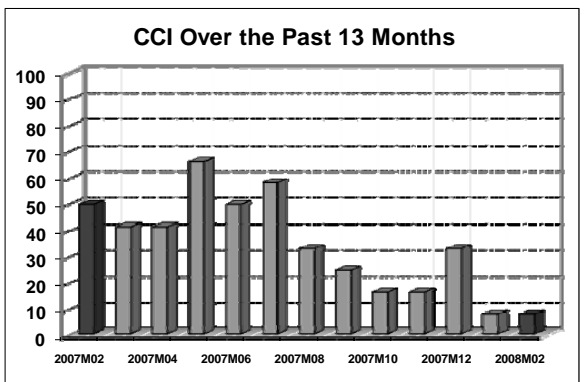

THE BOTTOM LINE

Economic activity in Rhode Island continued its substantia decline in February, exacerbated by the contractionary pressures that are occurring as the result of eliminating the largely selfimposed budget deficits we now face. The severity of this recession is an all-too-vivid illustration of how ineffective economic leadership actually hurts our state and its economy.

\begin{tabular}{|l|c|c|c|c|c|c|c|c|c|c|c|c|c|c|}
\hline & \multicolumn{3}{c|}{ Jan } & \multicolumn{1}{c}{ Feb } & Mar Apr & May Jun Jul Aug Sep Oct Nov Dec \\
\hline & 2007 & $50 \downarrow$ & $50 \downarrow$ & $42 \downarrow$ & 42 & 67 & $50 \downarrow$ & $58 \uparrow$ & 33 & $25 \downarrow$ & $17 \downarrow$ & $17 \downarrow$ & $33 \downarrow$ \\
2008 & 8 & 8 & & & & & & & & & & \\
\hline
\end{tabular}

